\title{
GENETIC DIVERSITY WITHIN NATURAL POPULATIONS OF THE MEDICINAL PLANT RHYNCHOSIA MINIMA (L.) DC.
}

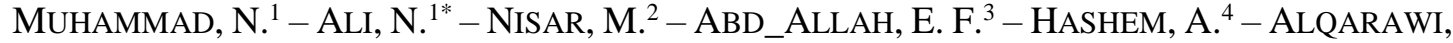 \\ A. ${ }^{3}-$ Aldubise, A. ${ }^{3}-$ KHAN, U. ${ }^{1}-$ RAHMAN, I. U. ${ }^{1}-$ AFZA, R. ${ }^{1}-$ KHAN, A. ${ }^{5}-$ AHMAD, H. ${ }^{6}$ \\ ${ }^{I}$ Department of Botany, Hazara University, Mansehra, Pakistan \\ ${ }^{2}$ Department of Botany, University of Malakand, Chakdara, Pakistan \\ ${ }^{3}$ Department of Plant Production, College of Food \& Agricultural Sciences, King Saud \\ University, P.O. Box 2460, Riyadh 11451, Saudi Arabia \\ ORCID ID (E. F. Abd_Allah): 0000-0002-8509-8953 \\ ${ }^{4}$ Department of Botany and Microbiology, College of Science, King Saud University, P.O. Box \\ 2460, Riyadh 11451, Saudi Arabia \\ ${ }^{5}$ Department of Microbiology, BUITEMS, Quetta, Pakistan \\ ${ }^{6}$ Islamia College University, Peshawar, Pakistan \\ *Corresponding author \\ e-mail: niazalitk25@gmail.com \\ (Received 20 $0^{\text {th }}$ May 2018; accepted $31^{\text {st }} \mathrm{Jul} 2018$ )
}

\begin{abstract}
Genetic diversity and relationships among 100 genotypes of Rhynchosia minima collected from four districts of Malakand Division was assessed using 16 morphological characteristics and total seed protein profile. Based on qualitative characteristics, inter-district trait similarity index among genotypes of Swat-Dir Lower and Swat-Buner was 100\%, while for Dir Lower-Buner, Dir Lower-Dir Upper, and Buner-Dir Upper, it was $85.71 \%, 28.57 \%$, and $42.85 \%$, respectively. Total seed protein profile resulted in 8 reproducible bands/loci, where inter-district locus contribution to the genetic disagreement was $75 \%$. Among the 8 loci, B-6 and B-7 were monomorphic and could be $R$. minima specific, whereas loci B-1, B4, B-5 and B-8 were observed only in genotypes collected from Buner. All but locus B-1 were present in genotypes of Dir Upper; locus B-8 was missing in genotypes from Dir Lower; loci B-1 and B-4 were absent in genotypes collected from Swat. Two-way cluster analysis resolved genotypes of District Buner and Dir Upper into discrete clusters, highlighting the role of habitat-specific adaptation. Genotypes of Dir Lower and Swat formed mosaic cluster, indicating to the transfer of genes and/or their coevolutionary descent. To the best of our understanding, this is the first ever report addressing genetic variability in $R$. minima.
\end{abstract}

Keywords: genetic variability, climate change, SDS-PAGE, two-way cluster analysis, Rynchosia

\section{Introduction}

Grain legumes are important dietary constituents for both humans and livestock and are ranked third in global importance after cereals and oilseeds (Ilyas et al., 2009; Naim-Feil et al., 2017). With the estimated rise in human population, food security is generally uncertain and warrants the need for safeguarding the biodiversity provided by nature and arable land for specific adaptation to stresses as well as ecosystem resilience under changing climatic conditions (Jacobsen et al., 2013; McCouch et al., 2013; Ali et al., 2016). Under these circumstances, demands for grain legume consumption will increase, and biotic and abiotic constraints will push the limits of legume production 
further (Ilyas et al., 2009). Nevertheless, the role of tropical grain legumes is critically important for areas where protein intake from animal sources is low. Population growth and limited land and water resources for agriculture are the major concerns that have gained considerable recent attention (Takeda and Matsuoka, 2008; McCouch et al., 2013). Although there have been consistent increases in crop productivity, these efforts are no longer meet the demands of future populations (Heslop-Harrison and Schwarzacher, 2012). Therefore, exploiting and tapping the wealth of wild and cultivated genetic resources provided by nature and currently warehoused in our seed repositories are vital (Tenskley and McCouch, 1997; Mujeeb-Kazi et al., 2017). However, in spite of all efforts, the world currently faces a greater demand on agricultural output than at any time in history (Tanksley and McCouch, 1997; Naim-Feil et al., 2017).

Indeed, plant breeders have been largely successful in developing high-yielding crop varieties; demands for greater yield potential were previously approached with genetic improvements coupled with increased farming inputs and addition to arable land (Helsop-Harrison and Schwarzacher, 2011). More recently, as the arable land surface has begun to shrink due to population growth, freshwater resources are becoming scarce, and agricultural inputs are associated with increased pollution; thus, major benefits will most likely result from genetic improvement of crops (Lobell et al., 2008; McCouch et al., 2013). However, the last several decades of intense plant breeding and selection are regarded as the most important force that has narrowed the genetic variability of crop species after their domestication some 10,000 years ago (Lu et al., 2009; Schwarzacher et al., 2011; Ali et al., 2012). Today, humanity depends on less than a dozen flowering plant species for $80 \%$ of all caloric intake (McCouch et al., 2013). Without sufficient adaptation measures in place, this will not be sufficient to support the feeding demands of 2050 in the face of climate change, habitat fragmentation, and limited water and land resources (Lobell et al., 2008; Mujeeb-Kazi et al., 2017).

Rhynchosia minima (L.) DC., a herbaceous, vining, perennial weed of the family Fabaceae, is found on all five continents (Lopez, 2012). The plant has considerable plasticity and can colonize disturbed areas as well as gaps within natural communities (Shaukat and Burhan, 2000). The plant has tremendous potential to be used in forage, pharmaceutical and other agricultural products, and more importantly, there are no known major threats to this species (Lopez, 2012); however, the plant has negligible uses worldwide, including in Pakistan. Traditionally, $R$. minima is applied to alleviate boils, colds, respiratory infections, diarrhea, dysentery and joint pains, and has been used as an abortifacient and an ecbolic and for general healing. It is also used as a food (in sweets), and its seeds are used as repellents and have antimicrobial potential. Furthermore, a number of important compounds that could fight cancer and may reduce carcinogenesis have been isolated from the seeds (Morris, 2008; Gweru et al., 2009; Jia et al., 2015).

A wide genetic base is critical to adaptation and will determine the future severity of climate change impacts. Genetic bottlenecks jeopardize the potential of crop species for sustainable agriculture and render them vulnerable to stresses (Ali et al., 2012, 2016; McCouch et al., 2013; Mujeeb-Kazi et al., 2017). With the continuous developments in DNA-based technologies and computational tools, more objective measurements of genetic diversity at the genomic level could be made, and important loci could be precisely mapped. 
However, not all of these tools are currently available to plant breeders in developing countries, which house large food-insecure human populations. Plant breeders still rely on traditional approaches to screen entries for a clearly defined character recognizable in the phenotype. Once a line with the desired characteristic is pinpointed, it is crossed with an elite cultivar in order to introduce the genes from the exotic donor into the cultivated type (Tanksley and McCouch, 1997; Mujeeb-Kazi et al., 2017).

Proteins are end products of gene expression, and measuring the diversity of the total seed proteins using the SDS-PAGE method is robust, inexpensive and important in practice to crops such as grain legumes (Nisar et al., 2009, 2016; Zahoor et al., 2015). Furthermore, seed storage protein markers have been successfully used to resolve taxonomic relationships and to identify potential lines in both wild and cultivated crop species (Lioi et al., 1999; Ghafoor et al., 2002; Nisar et al., 2007, 2009; Hameed et al., 2009; Win et al., 20011; Wadood et al., 2016). Overall, a combination of morphology with measurements of SDS-PAGE diversity of the total seed proteins has been largely successful, and the genetic diversity of seed storage proteins has been studied in many plant species of agronomic and commercial importance.

Our understanding of the potential of wild plant species and their objective diversity is still limited and needs enhancement (Payne, 1987; Rogl et al., 1996; Ali et al., 2016; Masood et al., 2017). To date, wild plants have received little attention, and thus, the main objective of the current study was to measure intraspecific genetic variation within the population of $R$. minima naturalized in different geographical regions. The present study was designed to study genetic relationships among natural populations of $R$. minima collected from four districts at random for morphological and seed storage protein evaluation. To the best of our understanding, the present study is the first documented report from Pakistan on the genetic diversity of $R$. minima.

\section{Materials and methods}

\section{Climatic conditions of Malakand division}

Malakand division in general is a hilly area located within the Northern Pakistan covering an area of nearly $29,872 \mathrm{Km}^{2}$ and having a range of climatic conditions (Fig. 1). Moving along the foothills of the Hindu Kush, Himalayas and Karakoram ranges, the climate of Malakand division changes from humid subtropical at the foothills to the typical arid climate characteristic of the plains of South Asia (Muhammad et al., 2016). District Swat stretches from $35.2227^{\circ}$ North to $72.4258^{\circ}$ East longitude and the climatic conditions varies from dry to moist temperate. The climate is influenced by various factors including latitude, altitude, the Indian Ocean Summer, Monsoon and the Western cyclonic currents, coming from the Mediterranean Sea, in the winter. Dir lower is located in the Dry temperate zone $\left(34.9161^{\circ} \mathrm{N}, 71.8097^{\circ} \mathrm{E} ; 4411 \mathrm{ft}\right.$ above sea level), Dir upper is a moist temperate region $\left(35.3356^{\circ} \mathrm{N}, 72.0468^{\circ} \mathrm{E}\right.$; $3174 \mathrm{ft}$ above sea level) while, District Buner having areas of both Dry and moist temperate regions $\left(34.3943^{\circ} \mathrm{N}, 72.6151^{\circ} \mathrm{E} ; 4049 \mathrm{ft}\right.$ above sea level).

\section{Plant materials}

Field trips were arranged during 2016-2017, and 100 genotypes of $R$. minima growing in the wild were collected from four districts of Malakand Division, Pakistan (i.e., 25 genotypes from each of District Swat, Dir lower, Buner and Dir upper) and are 
listed in Table Al in the Appendix. Plants were identified, the genotypes were labeled [first letter(s) corresponding to District, followed by species abbreviated name and accession number], and voucher specimens were submitted to the Herbarium at Hazara University Mansehra, Pakistan. These genotypes were assessed for estimation of interand intra-district variation and genetic diversity of morphological traits and total seed storage protein profile.
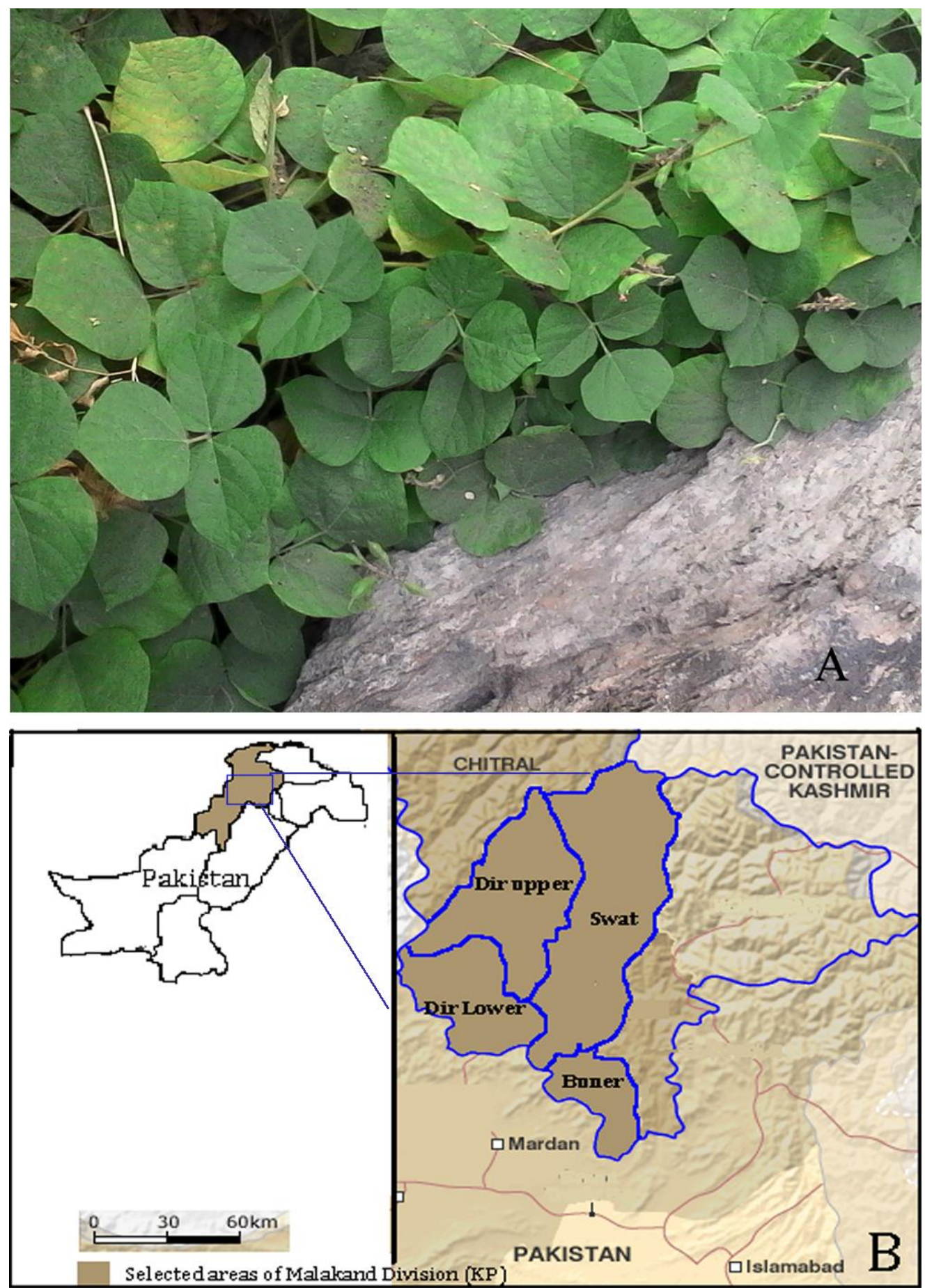

Figure 1. Rhynchosia minima plants growing on a rocky substrate (A) and map of the study $\operatorname{area}(B)$ 


\section{Morphological characterization}

Morphological characterization was registered on site and all randomly selected 25 mature genotypes were accounted (Fig. 1). A total of 16 morphological traits, including qualitative and quantitative traits, were scored. Qualitative traits were scored visually and encompassed leaf upper surface color (Luc), leaf lower surface color (Llc), inflorescence color (Ic), seed color (Sc), seed shape (Ss), hilum color (Hc) and testa texture (Tt). Quantitative traits were measured with the help of Vernier calipers or the centimeter scale and encompassed petiole length (PL), leaf length (LL), leaf width (LW), inflorescence length (IL), seed length (SL), seed weight (SW), seed thickness (ST), no. of pods per plant (PP) and 100 seed weight (SWT).

\section{Protein profiling}

For a total seed storage protein profile, sodium dodecyl polyacrylamide gel electrophoresis (SDS-PAGE) was performed following the method described by Laemmli (1970) and modified by Zahoor et al. (2015). A single seed of each genotype was crushed into a fine flour, and then $400 \mu \mathrm{l}$ of protein extraction buffer $(0.5 \mathrm{M}$ Tris$\mathrm{HCl}, 0.2 \%$ SDS, $5 \mathrm{M}$ urea, $1 \% \beta$-mercaptoethanol $\mathrm{pH} 8.0$ ) was added to $0.01 \mathrm{~g}$ of the fine seed powder in an Eppendorf tube and homogenized with a vortex. The mixture was kept for 20 min at room temperature (RT) for protein extraction. Bromophenol blue (BPB) was added to the sample buffer for observing protein sample movement. Samples were centrifuged at 13,000 rpm for $14 \mathrm{~min}$ at RT and the supernatant was transferred to a clean $1.5 \mathrm{ml}$ Eppendorf tube and run on a $12 \%$ polyacrylamide gel (composition of resolution gel: $3.0 \mathrm{M}$ Tris- $\mathrm{HCl} \mathrm{pH} 9.0,0.4 \%$ SDS and stacking gel $0.4 \mathrm{M}$ Tris- $\mathrm{HCl} \mathrm{pH}$ $7.0,0.4 \%$ SDS) at $100 \mathrm{~V}$ for $2 \mathrm{hrs}$. The gel was stained with Coomassie brilliant blue for $20 \mathrm{~min}$ and destained (5\% methanol, $20 \%$ acetic acid) until the background color disappeared.

\section{Data analysis}

Morphological and SDS-PAGE data were assembled in an MS Excel sheet. Twoway cluster analysis was based on binary data in PC-ORD software (Leps $`$ and $\mathrm{S} \asymp$ milauer, 2003). Genetic similarity estimates (F) were designed following Nei and Li (1979), and CANOCO software was used for specific loci/band enrichment in $R$. minima and to find the influence/relationship of the morphological traits and geographical origin on the total seed protein diversity in $R$. minima.

\section{Results and discussion}

\section{Morphological diversity in $R$. minima genotypes}

For morphological diversity, both the qualitative and quantitative characteristics were assessed, revealing substantial variability among genotypes for most traits: plants collected from different districts harbored higher variability than genotypes from within the same district. Descriptive statistics of the morphological parameters are summarized in Table 1. The CV\% was calculated for petiole length, leaf length, leaf width, stipule length, inflorescence length, seed length, seed width and seed thickness, No. of pods per plant, 100 seed weight. 
Table 1. Descriptive statistics of the important morphological parameters

\begin{tabular}{|c|c|c|c|c|c|c|}
\hline $\begin{array}{c}\text { Area/site of } \\
\text { collection }\end{array}$ & Traits & Minimum & Maximum & Mean & Std. Deviation & CV\% \\
\hline \multirow{9}{*}{ 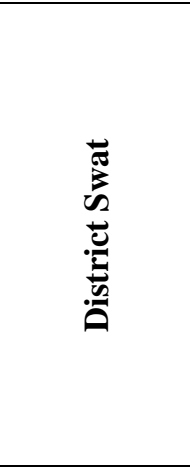 } & PL & 1.3 & 1.94 & 1.5749 & 0.20889 & 13.2637 \\
\hline & LL & 81.98 & 101.98 & 94.7232 & 5.06394 & 5.3461 \\
\hline & $\mathbf{L W}$ & 15.33 & 33.67 & 22.58 & 3.74443 & 16.582 \\
\hline & IL & 1.67 & 4.33 & 3.2 & 0.63828 & 19.943 \\
\hline & SL & 5.67 & 9 & 7.684 & 0.87428 & 11.377 \\
\hline & SW & 2.67 & 5 & 3.972 & 0.52323 & 13.172 \\
\hline & ST & 1.6 & 3.17 & 2.516 & 0.38371 & 15.251 \\
\hline & $\mathbf{P} / \mathbf{P}$ & 12.67 & 34 & 22.2667 & 6.08428 & 27.324 \\
\hline & SWT & 24 & 33 & 28.544 & 2.44916 & 8.581 \\
\hline \multirow{9}{*}{ 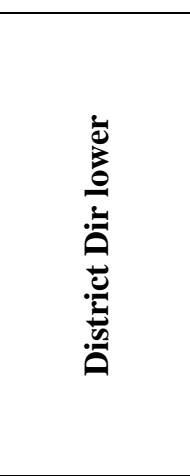 } & PL & 2 & 2.99 & 2.654 & 0.28634 & 10.789 \\
\hline & $\mathbf{L L}$ & 107.6 & 137.8 & 128 & 7.04929 & 5.518 \\
\hline & $\mathbf{L W}$ & 19.67 & 112 & 79.072 & 32.28988 & 40.836 \\
\hline & IL & 3 & 7.33 & 5.0493 & 1.31576 & 26.0582 \\
\hline & SL & 2.96 & 8 & 4.3708 & 1.22465 & 28.018 \\
\hline & SW & 1.83 & 4.2 & 2.9333 & 0.54815 & 18.687 \\
\hline & ST & 1.23 & 3.27 & 2.536 & 0.57702 & 22.752 \\
\hline & $\mathbf{P} / \mathbf{P}$ & 23 & 40.33 & 33.6933 & 4.02989 & 11.961 \\
\hline & SWT & 9 & 33 & 14.0684 & 7.74323 & 55.0398 \\
\hline \multirow{9}{*}{ 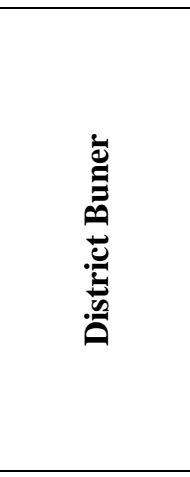 } & PL & 6 & 6.99 & 6.5473 & 0.33476 & 5.112 \\
\hline & $\mathbf{L L}$ & 63.33 & 89.78 & 73.6398 & 6.29928 & 8.554 \\
\hline & $\mathbf{L W}$ & 36 & 122.67 & 71.5239 & 27.31532 & 38.191 \\
\hline & IL & 3.33 & 6 & 4.1733 & 0.90329 & 21.644 \\
\hline & SL & 2.65 & 8.23 & 4.8076 & 1.30897 & 27.227 \\
\hline & SW & 1.67 & 6.8 & 3.1561 & 1.04537 & 33.122 \\
\hline & ST & 1.57 & 3.63 & 2.6128 & 0.57634 & 22.058 \\
\hline & $\mathbf{P} / \mathbf{P}$ & 35.67 & 78.67 & 59.9733 & 17.37813 & 28.976 \\
\hline & SWT & 9.3 & 15 & 12.6412 & 1.7454 & 13.809 \\
\hline \multirow{10}{*}{ 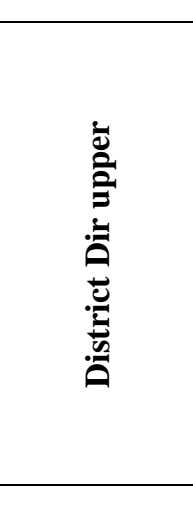 } & PL & 3.99 & 5.8 & 4.3719 & 0.37533 & 8.585 \\
\hline & $\mathbf{L L}$ & 23.25 & 34 & 29.223 & 2.53127 & 8.661 \\
\hline & $\mathbf{L W}$ & 17 & 115 & 46.78 & 25.44987 & 54.401 \\
\hline & IL & 1.67 & 7.67 & 4.7733 & 1.55075 & 32.488 \\
\hline & SL & 2.67 & 8.67 & 6.1688 & 1.83278 & 29.711 \\
\hline & SW & 1.57 & 4.67 & 3.3835 & 0.85506 & 25.271 \\
\hline & ST & 1.43 & 3.37 & 2.3399 & 0.51268 & 21.911 \\
\hline & $\mathbf{P} / \mathbf{P}$ & 13 & 77.33 & 45.1867 & 24.76315 & 54.801 \\
\hline & SWT & 12.14 & 33 & 20.5656 & 7.39849 & 35.975 \\
\hline & \multicolumn{6}{|c|}{$\mathrm{CV} \%=$ Std. Deviation/Mean $* 100$} \\
\hline
\end{tabular}

$\mathrm{PL}=$ petiole length, $\mathrm{LL}=$ leaf length, $\mathrm{LW}=$ leaf width, $\mathrm{SL}=$ seed length, $\mathrm{SW}=$ seed width, $\mathrm{ST}=$ seed thickness, $\mathrm{P} / \mathrm{P}=$ no. of pods/plant, $\mathrm{SWT}=100$ seed weight 
Petiole length in genotypes collected from district Swat was $13.2637 \%$, for district Dir lower was 10.789, for district Buner was 5.112 and for district Dir Upper was 8.585. Significant variation was found for the leaf length among the genotypes of four districts; the highest value was observed for genotypes collected from district Buner (8.554) followed by district Dir Upper (8.661\%) and Dir lower $(5.518 \%)$ while, lowest value was recorded for the genotypes collected from Swat $(5.3461 \%)$. For leaf width in genotypes collected from Swat was (16.582\%), Dir lower (40.836\%), for district Buner (38.191\%) whereas for district Dir Upper was $54.401 \%$. Furthermore highest variation was observed for seed length and seed width. Number of pods/plant varied for genotypes collected from Swat, Dir lower, Buner and Dir Upper was 27.324\%, $11.961 \%, 28.976 \%$ and $54.801 \%$ respectively (Table 1 ).

Based on qualitative characteristics, the inter-district trait similarity index among genotypes of Swat-Dir Lower and Swat-Buner was 100\%, while for Swat- Dir Upper, Dir Lower-Buner, Dir Lower-Dir Upper, and Buner-Dir Upper, it was 28. 571, 85.71\%, $28.57 \%$, and $42.85 \%$, respectively (Table 2). Similarly, based on quantitative traits inter-district traits similarity index among genotypes of Swat-Dir Lower, Swat-Dir Upper, Swat-Buner, Dir lower-Buner and Dir upper-Swat was 22.2\%; while for Dir Lower-Dir upper was 11.1\%; Buner-Dir upper was $33.333 \%$ and that of Buner-Dir Upper was $42.85 \%$. Furthermore, the Pearson correlation coefficient revealed a significant positive as well as a negative association ( $\mathrm{p}=0.05$ and 0.01$)$ among the studied traits of $R$. minima (Tables 3 and 4). Several traits revealed strong interrelationships within phenotype categories, particularly leaf traits with yield contributing traits and a few traits correlating with other categories, such as inherently linked growth and phenology-related traits (Tables 2 and 3). Furthermore, quantitative data set of 100 genotypes was used for cluster analysis. The dendrogram resolved all the 100 genotypes of $R$. minima into four discrete clusters (groups), each representing the geographical origin of collection and highlighting the determining role of geography rather than variation within the traits themselves (Fig. 2).

Table 2. Region-wise trait similarity index based on qualitative traits

\begin{tabular}{|c|c|c|c|c|c|c|c|c|c|}
\hline \multirow[b]{2}{*}{ Traits } & \multirow[b]{2}{*}{ S-RM } & \multirow[b]{2}{*}{ DL-RM } & \multirow[b]{2}{*}{ B-RM } & \multirow[b]{2}{*}{ DU-RM } & \multicolumn{5}{|c|}{ Traits similarity index } \\
\hline & & & & & $\begin{array}{l}\text { S-RM \& } \\
\text { DL-RM }\end{array}$ & $\begin{array}{c}\text { S-RM \& } \\
\text { B-RM }\end{array}$ & $\begin{array}{c}\text { DL-RM \& } \\
\text { B-RM }\end{array}$ & \begin{tabular}{|c|} 
DL-RM \& \\
DU-RM
\end{tabular} & $\begin{array}{c}\text { B-RM \& } \\
\text { DU-RM }\end{array}$ \\
\hline Luc & Green & Green & Green & $\begin{array}{l}\text { Moss } \\
\text { green }\end{array}$ & Green & Green & NA & NA & NA \\
\hline Llc & Green & Green & Green & $\begin{array}{l}\text { Yellow } \\
\text { green }\end{array}$ & Green & Green & Green & NA & NA \\
\hline Ic & $\begin{array}{l}\text { White } \\
\text { yellow }\end{array}$ & $\begin{array}{l}\text { White } \\
\text { yellow }\end{array}$ & $\begin{array}{l}\text { White } \\
\text { yellow }\end{array}$ & $\begin{array}{l}\text { Yellow } \\
\text { green }\end{array}$ & $\begin{array}{l}\text { White } \\
\text { yellow }\end{array}$ & $\begin{array}{l}\text { White } \\
\text { yellow }\end{array}$ & white yell & NA & NA \\
\hline Sc & Brown & Brown & Brown & $\begin{array}{c}\text { Dull } \\
\text { yellow }\end{array}$ & Brown & Brown & Brown & NA & NA \\
\hline Ss & Oblong & Oblong & Oblong & Oblong & Oblong & Oblong & Oblong & Oblong & Oblong \\
\hline Hc & White & White & $\begin{array}{l}\text { White } \\
\text { yellow }\end{array}$ & $\begin{array}{l}\text { White } \\
\text { yellow }\end{array}$ & White & White & $\begin{array}{l}\text { White } \\
\text { yellow }\end{array}$ & NA & $\begin{array}{l}\text { White } \\
\text { yellow }\end{array}$ \\
\hline $\mathbf{T t}$ & Smooth & Smooth & Smoth & Smoth & Smoth & Smoth & Smoth & Smoth & Smoth \\
\hline \multicolumn{5}{|c|}{ TSI $=$ homologous traits/Total traits $* 100=$} & 100 & 100 & 85.71 & 28.57 & 42.85 \\
\hline
\end{tabular}

Luc = leaf upper surface colour, Llc = leaf lower surface colour, Ic =Inflorescence color, Sc $=$ Seed color, $\mathrm{Ss}=$ Seed shape, $\mathrm{Hc}=$ Hilum Color, $\mathrm{Tt}=$ Testa texture, $\mathrm{S}=\mathrm{Swat}, \mathrm{DL}=\mathrm{Dir}$ lower, $\mathrm{DU}=\mathrm{Dir}$ upper, $\mathrm{B}=$ Buner, $\mathrm{RM}=\mathrm{R}$. minima 
Table 3. Correlation coefficient among nine quantitative traits of DL-RM (italic numbers) and $S-R M$

\begin{tabular}{|c|c|c|c|c|c|c|c|c|c|}
\hline Traits & PL & $\mathbf{L L}$ & $\mathbf{L W}$ & IL & SL & SW & ST & $\mathbf{P} / \mathbf{P}$ & SWt \\
\hline PL & 1.00 & $-0.501 *$ & 0.01 & 0.39 & $0.884 * *$ & $-0.580 * *$ & $-.910 * *$ & -0.07 & $-0.743 * *$ \\
\hline $\mathbf{L L}$ & -0.08 & 1.00 & -0.03 & -0.28 & $-0.450^{*}$ & 0.20 & $.432 *$ & 0.22 & 0.36 \\
\hline LW & 0.12 & 0.18 & 1.00 & $0.405^{*}$ & 0.25 & $-0.540 * *$ & 0.15 & -0.08 & -0.27 \\
\hline IL & -0.48 & 0.34 & 0.21 & 1.00 & $.659 * *$ & -0.30 & -0.27 & -0.01 & -0.08 \\
\hline SL & 0.39 & -0.37 & 0.06 & -0.33 & 1.00 & $-0.543 * *$ & $-0.765 * *$ & -0.03 & -0.07 \\
\hline SW & $0.524^{* *}$ & -0.34 & -0.06 & -0.34 & $0.828^{* * *}$ & 1.00 & $.417 *$ & 0.17 & $0.622 * *$ \\
\hline ST & $0.402^{*}$ & -0.36 & 0.11 & -0.09 & $0.611^{* *}$ & $0.707 * *$ & 1.00 & $0.641^{* *}$ & -0.08 \\
\hline $\mathbf{P} / \mathbf{P}$ & 0.39 & -0.17 & -0.16 & -0.03 & -0.14 & 0.13 & 0.18 & 1.00 & 0.14 \\
\hline SWt & -0.13 & -0.31 & -0.20 & -0.25 & 0.23 & 0.32 & 0.07 & 0.20 & 1.00 \\
\hline
\end{tabular}

*Correlation is significant at the 0.05 level (2-tailed)

**Correlation is significant at the 0.01 level (2-tailed)

$\mathrm{PL}=$ petiole length, $\mathrm{LL}=$ leaf length, $\mathrm{LW}=$ leaf width, $\mathrm{IL}=$ inflorescence, $\mathrm{SL}=$ seed length, $\mathrm{SW}=$ seed weight, $\mathrm{ST}=$ seed thickness, $\mathrm{P} / \mathrm{P}=$ no. of pod/plant, $\mathrm{SWT}=$ seed weight. $\mathrm{S}=$ swat, $\mathrm{DL}=\mathrm{Dir}$ lower, $\mathrm{RM}=\mathrm{R}$. minima

Table 4. Correlation coefficient among nine quantitative traits of DU-RM (italic numbers) and $B-R M$

\begin{tabular}{|c|c|c|c|c|c|c|c|c|c|}
\hline Traits & PL & LL & LW & IL & SL & SW & ST & $\mathbf{P} / \mathbf{P}$ & SWt \\
\hline PL & 1.00 & 2 & 0.01 & $0.658 * *$ & $0.811 * *$ & $-0.841 * *$ & $-0.888 * *$ & -0.19 & -0.34 \\
\hline LL & $-0.415^{*}$ & 1.00 & -0.33 & $-0.662 * *$ & $-0.828 * *$ & $0.817 * *$ & $0.878 * *$ & 0.11 & 0.32 \\
\hline LW & -0.21 & 0 . & 1.00 & 0.27 & -0.05 & -0.18 & -0.24 & $0.636^{* *}$ & $0.791 * *$ \\
\hline IL & -0.35 & $0.657^{* *}$ & ה & 1.00 & 0.04 & -0.15 & $-0.525 * *$ & $-0.565 * *$ & $0.911 * *$ \\
\hline SL & 0.37 & -0.32 & -0.12 & 0.11 & 1.00 & -0.08 & -0.11 & $-0.707 * *$ & $-0.695 * *$ \\
\hline SW & 0.15 & 0.02 & 0.30 & $0.434 *$ & $0.806^{* *}$ & 1.0 & 0.19 & $0.519 * *$ & $0.862 * *$ \\
\hline ST & -0.03 & 0.04 & 0.28 & $0.444 *$ & $0.448^{*}$ & $0.602 * *$ & 1.00 & 0.18 & 0.33 \\
\hline $\mathbf{P} / \mathbf{P}$ & 0.35 & $-0.407 *$ & $-0.936^{* *}$ & $-0.695 * *$ & 0.11 & -0.34 & -0.37 & 1.00 & -0.18 \\
\hline SWt & 0.24 & -0.23 & $-0.747 * *$ & $-0.552 * *$ & -0.20 & $-0.528 * *$ & $-0.530 * *$ & $.800 * *$ & 1.00 \\
\hline
\end{tabular}

*Correlation is significant at the 0.05 level (2-tailed)

**Correlation is significant at the 0.01 level (2-tailed)

$\mathrm{PL}=$ petiole length, LL = leaf length, LW = leaf width, IL = inflorescence, SL = seed length, $\mathrm{SW}=$ seed weight, $\mathrm{ST}=$ seed thickness, $\mathrm{P} / \mathrm{P}=$ no. of pod $/$ plant, $\mathrm{SWT}=$ seed weight. $\mathrm{DU}=\mathrm{Dir}$ upper, $\mathrm{B}=$ buner, $\mathrm{RM}=\mathrm{R}$. minima

\section{SDS-PAGE analysis}

For exploration of genetic polymorphisms, modern tools can provide better understanding of species relationships and heterogeneity. Furthermore, morphometric, biochemical and molecular marker approaches have been used for examining genetic diversity and for inferring the intra- and interspecies relationships in plants (Tomooka et 
al., 2002). Moreover, isozymes (Jaaska and Jaaska, 1990), low-molecular-weight carbohydrates (Yasui et al., 1985), RFLPs (Fatokun et al., 1993), and nuclear as well as chloroplast DNA, (Vaillancourt and Weeden, 1993), RAPDs (Kaga et al., 1996), SSRs, EST-SSRs (Ali et al., 2016) and AFLPs (Tomooka et al., 2002), among others, have been used to study crop species.

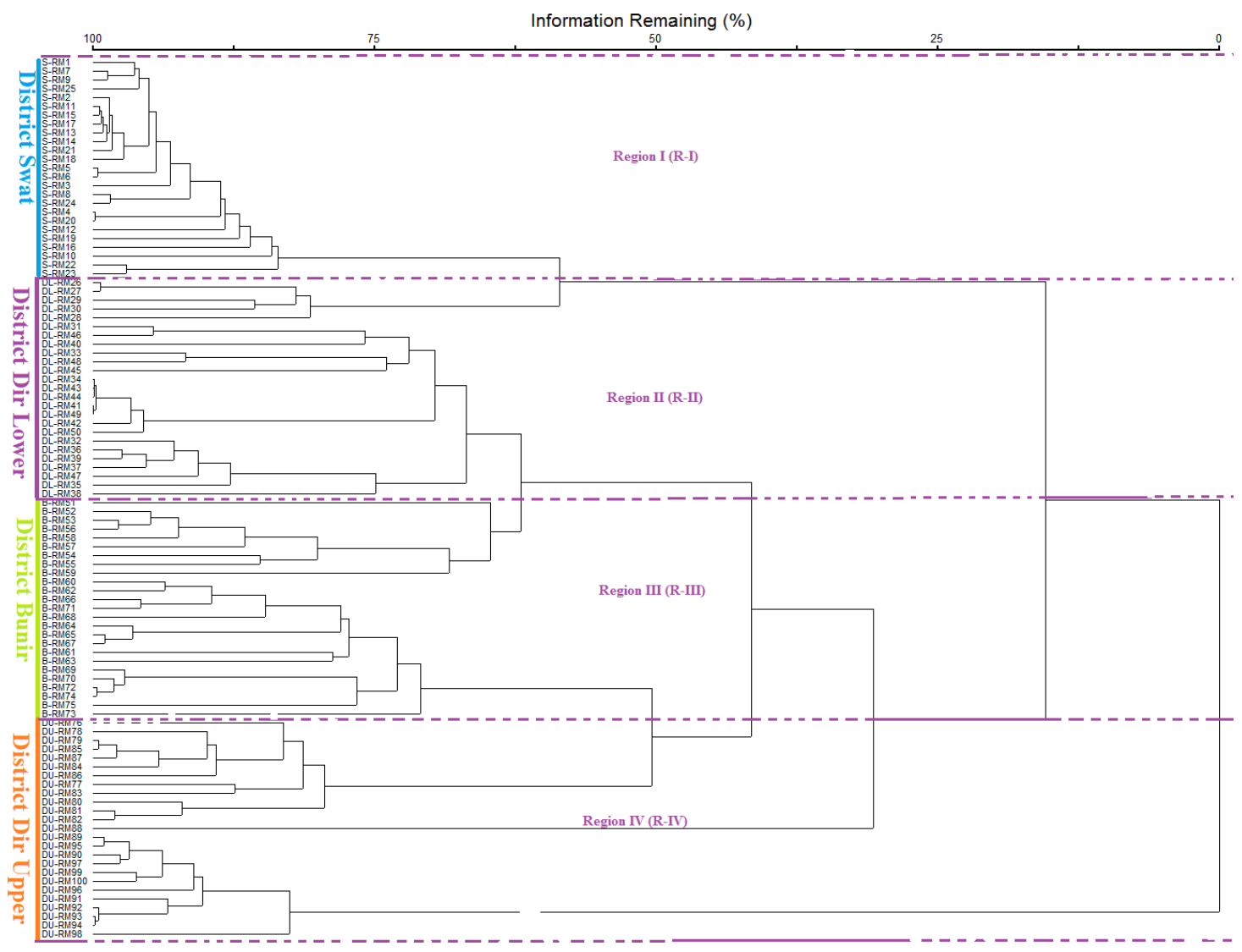

Figure 2. Intra-species relationship identified through morphological characteristics in different genotypes of R. minima collected from four districts of Malakand Division, Pakistan. $R M$ indicates $R$. minima, $S=S w a t, D L=$ Dir lower, $B=$ Buner and $D U=$ Dir upper

Eight reproducible bands of $\sim 10-180 \mathrm{kDa}$ were observed in the $R$. minima; a representative PAGE is shown (Fig. 3). The binary data of these loci were used to estimate relationships among all genotypes with cluster analysis, and all $R$. minima were divided into six clusters (Fig. 4). In cluster-1 (also referred to as Region I, R-I), genotypes collected from District Buner were resolved as having 25\% genetic diversity, whereas genotypes of R-II consisted of samples collected from District Dir Upper with $24.07 \%$ genetic diversity among genotypes. Genotypes in R-III belonged to District Dir lower with $29.37 \%$ genetic variation among genotypes, and R-IV genotypes collected from District Swat had 50\% diversity. Similarly, genotypes in R-V and R-VI consisted of genotypes of $R$. minima collected from Dir lower (5 genotypes) and Swat (13 genotypes with $48.07 \%$ genetic diversity).

SDS-PAGE has shown promise in understanding the genetic relationships in angiosperms at the generic as well as at the species levels and is reliable for assessing polymorphisms in crops (Payne, 1987; Ghafoor et al., 2002; Nisar et al., 2009; Win et 
al., 2011; Zahoor et al., 2015). The results for the mean square values and response of protein loci/band enrichment within genotypes showed significant variations as indicated (Fig. 5). Variability in color and size indicates variation, and the speciesspecific loci B-6 and B-7 revealed maximum enrichment (present in 100\% genotypes), followed by B-8 (72\%), B-5 (69\%), B-4 (65\%), B-3 (63\%) and B-2 (50). Furthermore, loci B-2 and B-3 were negatively associated with B-1, B-4 and B-5, while B-8, B-6 and B7 have a neutral association because these bands are evenly distributed among the $R$. minima genotypes collected from these four geographical areas (Fig. 5). The overall inter-district locus contribution towards the genetic disagreement was $75 \%$, whereas within the district, it varied from 0.00 to $75 \%$. Among the 8 loci, B-6 and B-7 were monomorphic, present in all genotypes and are likely to be species specific. In contrast, loci B-1, B-4, B-5 and B-8 were observed in genotypes collected from Buner, whereas these genotypes were missing loci B-2 and B-3 and genotypes collected from Dir Upper had all loci except B-1. R. minima genotypes collected from Dir Lower and Swat had a mixed protein profile, i.e., showing higher diversity and intermixing within the genotypes. This indicates frequent gene flow within these genotypes and their potential to withstand extreme environmental events (Fig. 4 and Table 5). Details of all of these loci and whether they are monomorphic or polymorphic have been determined and are given in Table 5. There was a high inter-district locus contribution towards genetic disagreements among $R$. minima genotypes; SDS-PAGE could be a consistent procedure for documentation of these genotypes, while intra-district locus contributions towards genetic disagreement in genotypes of $R$. minima collected from Swat (S-RM) and Dir lower (DL-RM) were high (100\%) compared to those from Buner (B-RM) at $85.71 \%$ and from Dir upper (DU-RM) at $28.57 \%$ (Table 2).
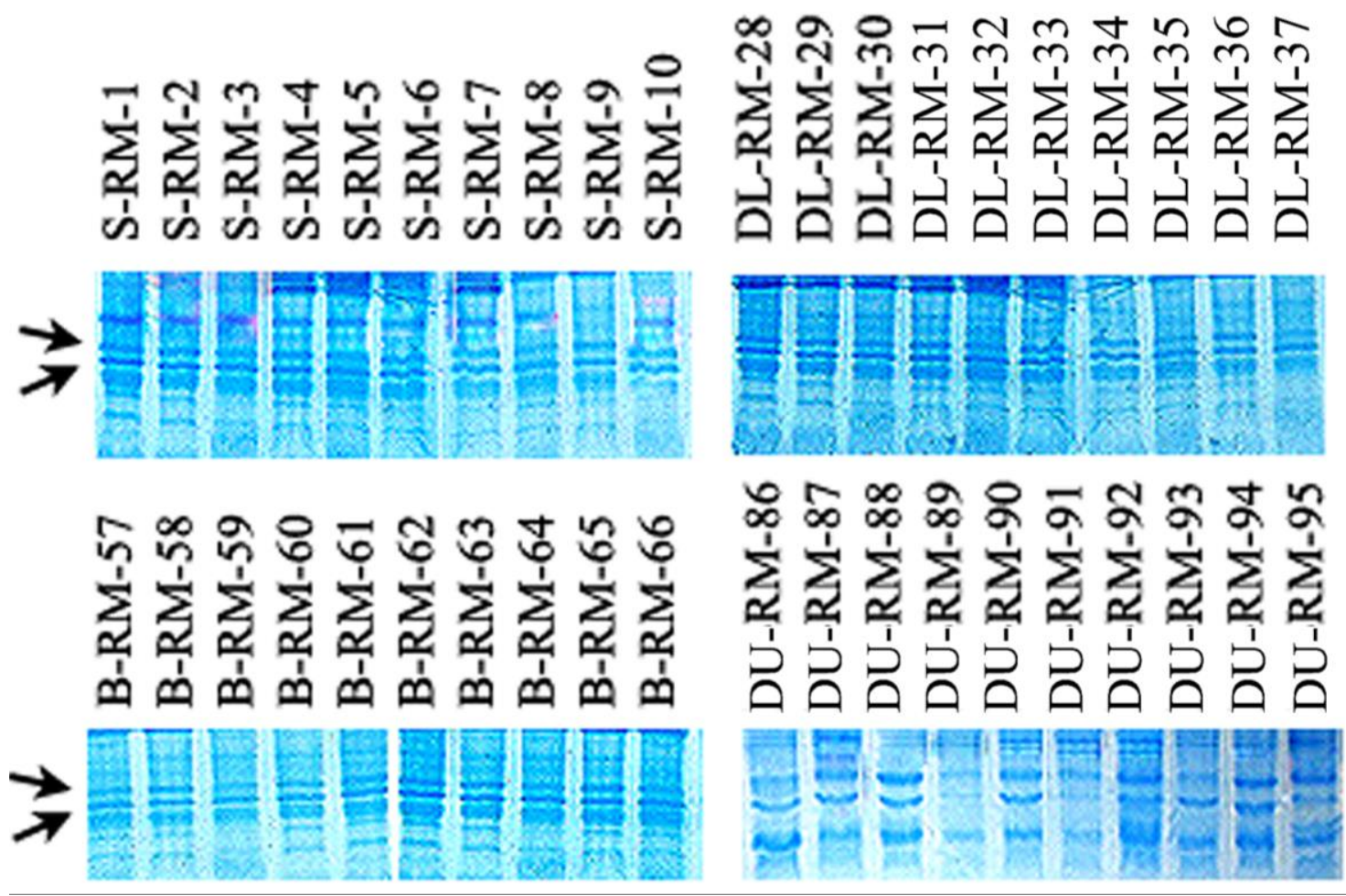

Figure 3. Representative polyacrylamide gel (12\%) electrophoresis showing diversity in total seeds storage proteins among different genotypes of $R$. minima. Arrow indicates the speciesspecific loci (B6, B7). $S=$ Swat, $D L=$ Dir lower, $B=$ Buner, $D U=$ Dir upper, $R M=R$. minima 


\begin{tabular}{|c|c|c|c|c|c|}
\hline R-I & R-II & R-III & R-IV & R-V & R-VI \\
\hline $25 \%$ & 24.0796 & $29.37 \%$ & 5096 & $57.5 \%$ & 48.0796 \\
\hline
\end{tabular}
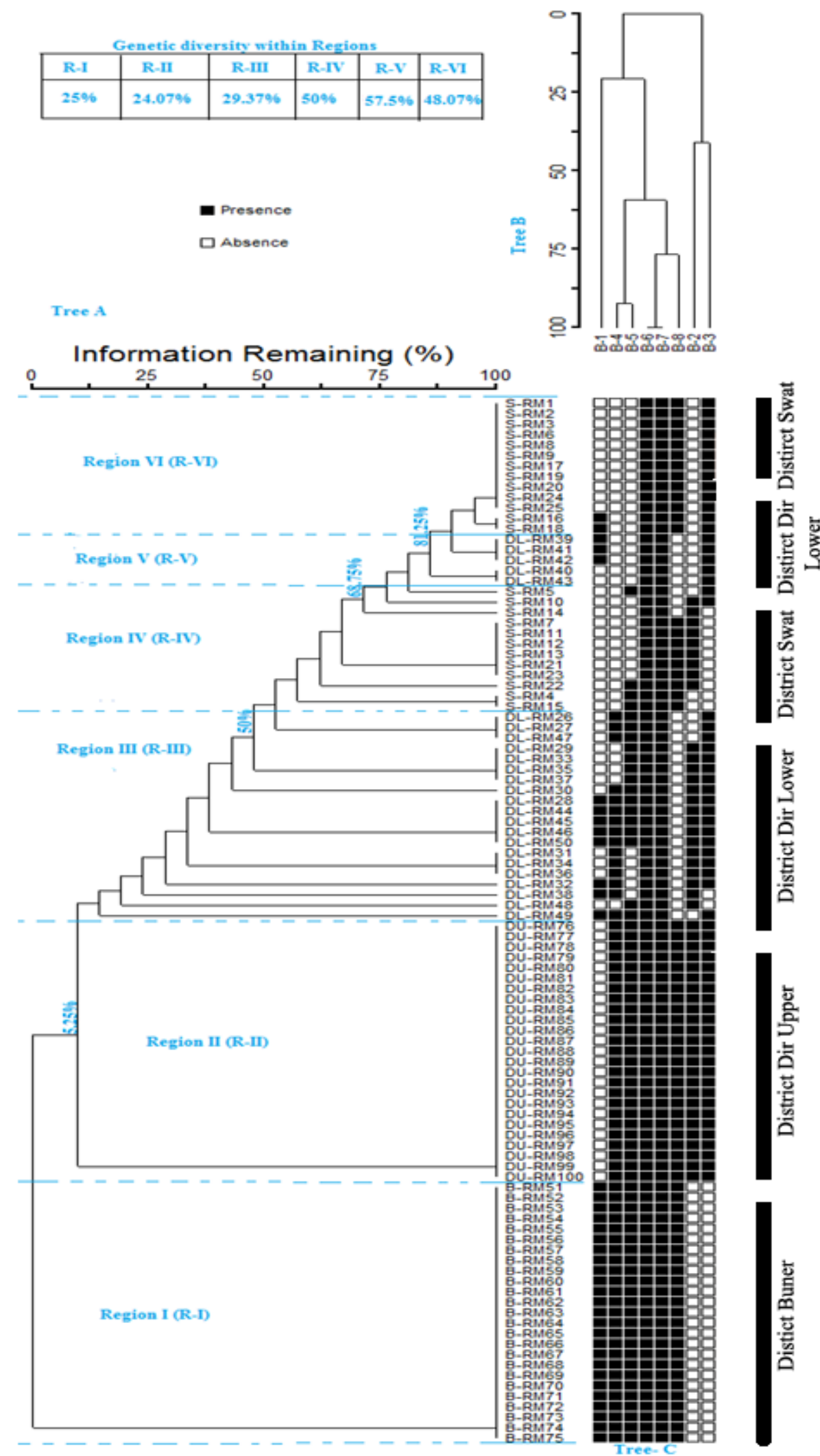

Figure 4. Two-way cluster dendrogram based on the presencelabsence of seed protein bands in different genotypes of R. minima species collected from four districts of Malakand Division, Khyber Pakhtunkhwa, Pakistan. RM indicates genotypes of $R$. minima, $S=S w a t, D L=D i r$ lower, $B=$ Buner and $D U=$ Dir upper 


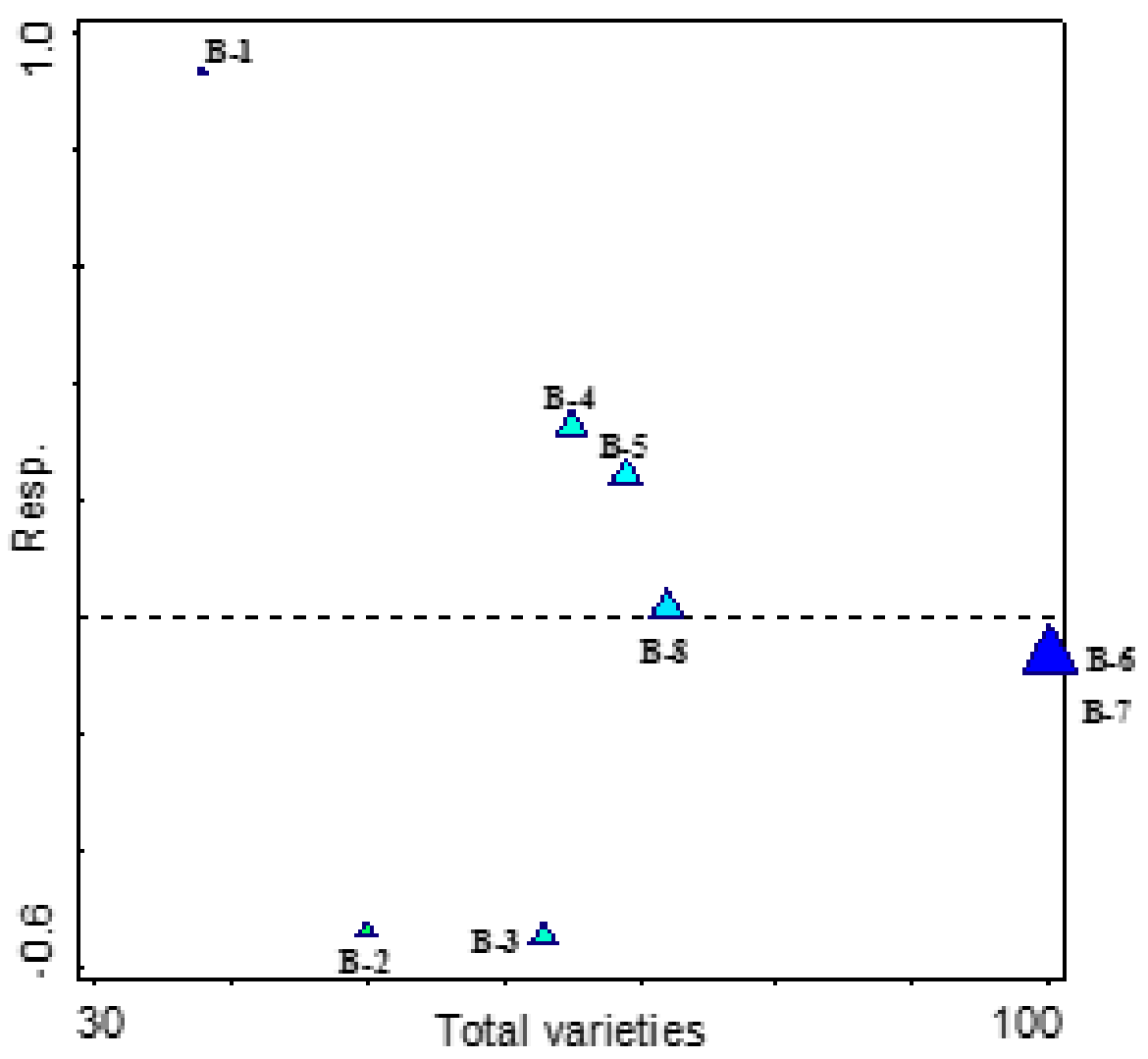

Figure 5. Different colours showing the R. minima genotype (X-axis) enrichment on the basis of particular loci/band categories

These four Districts are located adjacent to one another, but altogether, they cover an area of approximately $12,484 \mathrm{~km}^{2}$, and each District is characterized by distinct environmental conditions and vegetation types. Nonetheless, the wide ecological amplitude and genomic plasticity of $R$. minima allow it to invade new areas and gaps within established plant communities (Shaukat and Burhan, 2000; Jia et al., 2015). This highlights the potential of finding useful genes for adaptation and climatic resilience as well as introgression of genes for improving productivity and resistance in leguminous crops via intergeneric crosses. We have no evidence whether such intergeneric crosses are likely to be successful, but wide crosses (interspecific and intergeneric) have been reported to be tremendously successful in cereals (Ali et al., 2012; Masood et al., 2016; Mujeeb-Kazi et al., 2017). There are numerous reports where not only cultivated plants but also their distant wild relatives have been hybridized successfully, and the size of the alien chromatin associated with linkage drag has then been reduced while still retaining the useful trait (Schwarzacher et al., 2011; Ali et al., 2016; Patokar et al., 2016; Mujeeb-Kazi et al., 2017).

To the best of our knowledge, this is the first study addressing diversity in $R$. minima, although we have no idea whether the seed storage proteins were overlapping as reported in other legumes. Therefore, no attempt was made to assign the recorded polypeptides into respective classes, i.e., legumin and vicilin (Mirali et al., 2007). Instead, for fine resolution, the dendrogram was divided into six regions, and genotypes collected from District Dir lower and Swat segregated with one another, while genotypes from District Dir upper and Buner assorted into discrete clades/groups 
(Fig. 4). R. minima enrichment on the basis of specific seed protein bands indicated that B-6 and B-7 were species specific and present in all genotypes (Fig. 5). The presence of common loci (B-6 and B-7) among these genotypes suggests their close genetic similarity and common ancestry. These loci encoded proteins that have been fixed in different genotypes of Rhynchosia over evolutionary time. These findings are in agreement with those of Azeez and Morakinyo (2004), who associated the presence of common protein bands in Lycopersicum and Trichosanthes species with their common evolutionary origin.

Table 5. Intra- and inter-district genetic diversity among $R$. minima genotypes

\begin{tabular}{|c|c|c|c|c|c|c|c|}
\hline Regions & Expressed loci & Status & GD\% & Regions & Expressed loci & Status & GD\% \\
\hline \multirow{8}{*}{ S-RM } & 1 & Poly & 0.4 & \multirow{8}{*}{$\mathrm{B}-\mathrm{RM}$} & 25 & Mono & 0.25 \\
\hline & 9 & Poly & 0.36 & & 25 & Mono & 0.00 \\
\hline & 14 & Poly & 0.56 & & 0.00 & Mono & 0.00 \\
\hline & 0.00 & Mono & 0.00 & & 0.00 & Mono & 0.25 \\
\hline & 4 & Poly & 0.16 & & 25 & Mono & 0.25 \\
\hline & 25 & Mono & 1.00 & & 25 & Mono & 1.00 \\
\hline & 25 & Mono & 1.00 & & 25 & Mono & 1.00 \\
\hline & 21 & Poly & 0.84 & & 25 & Mono & 0.25 \\
\hline \multicolumn{4}{|c|}{ GD $=$ poly/Total loci $* 100=62.5$} & \multicolumn{4}{|c|}{ GD $=$ poly/Total loci $* 100=0.00$} \\
\hline \multirow{8}{*}{ DL-RM } & 11 & Poly & 0.44 & \multirow{8}{*}{ DU-RM } & 0.00 & Mono & 0.25 \\
\hline & 16 & Poly & 0.64 & & 25 & Mono & 0.00 \\
\hline & 23 & Poly & 0.23 & & 25 & Mono & 0.00 \\
\hline & 15 & Poly & 0.6 & & 25 & Mono & 0.25 \\
\hline & 15 & Poly & 0.6 & & 25 & Mono & 0.25 \\
\hline & 25 & Mono & 1.00 & & 25 & Mono & 1.00 \\
\hline & 25 & Mono & 1.00 & & 25 & Mono & 1.00 \\
\hline & 0.00 & Mono & 0.00 & & 25 & Mono & 0.25 \\
\hline \multicolumn{4}{|c|}{ GD $=$ poly $/$ Total loci $* 100=75$} & & \multicolumn{3}{|c|}{ GD $=$ poly/Total loci $* 100=0.00$} \\
\hline \multicolumn{8}{|c|}{ Inter district variation in $R$. minima genotypes } \\
\hline \multicolumn{3}{|c|}{ Expressed loci } & \multicolumn{4}{|l|}{ Status } & GD\% \\
\hline \multicolumn{3}{|l|}{37} & \multicolumn{4}{|l|}{ Poly } & 0.37 \\
\hline \multicolumn{3}{|l|}{50} & \multicolumn{4}{|l|}{ Poly } & 0.5 \\
\hline \multicolumn{3}{|l|}{62} & \multicolumn{4}{|l|}{ Poly } & 0.62 \\
\hline \multicolumn{3}{|l|}{65} & \multicolumn{4}{|l|}{ Poly } & 0.65 \\
\hline \multicolumn{3}{|l|}{69} & \multicolumn{4}{|l|}{ Poly } & 0.16 \\
\hline \multicolumn{3}{|l|}{100} & \multicolumn{4}{|l|}{ Mono } & 1.00 \\
\hline \multicolumn{3}{|l|}{100} & \multicolumn{4}{|l|}{ Mono } & 1.00 \\
\hline \multicolumn{3}{|l|}{71} & \multicolumn{4}{|l|}{ Poly } & 0.71 \\
\hline
\end{tabular}

Intra locus contribution toward GD poly/Total $* 100=75$

$\mathrm{S}=$ swat, $\mathrm{B}=$ buner $\mathrm{DL}=$ Dir lower, $\mathrm{DU}=$ Dir upper, $\mathrm{RM}=$ Rhynchosia minima, $\mathrm{GD}=$ genetic disagreement

Detrended correspondence analysis (DCA) revealed grouping and distribution of $R$. minima genotypes into four patches on the basis of their geographical origin coupled 
with the data of morphological as well as total seed protein diversity. Area of collection (origin) played a marked role in the grouping of $R$. minima genotypes as well as a positive/negative association with a particular set of morphological traits and seed protein profile (Fig. 6). Furthermore, comparison of the two cluster dendrograms were in general agreement with one another, indicating the stability of the morphological traits and the potential of $R$. minima to adapt to various climatic and soil conditions (compare Figs. 2 and 4). The DCA plot revealed important information regarding the distribution of genotypes with morphological traits and total seed protein profile. Here, the role of geographical origin again was overwhelming and leaf-related traits as well as protein loci B-1 had a strong and positive impact (Fig. 6). It will be extremely interesting to study specific genes in $R$. minima that allow adaptation to new habitats and to compare them to those that have previously played an important role in plant domestication under human influence (Baudoin and Marechal, 1985; Chen et al., 2006).

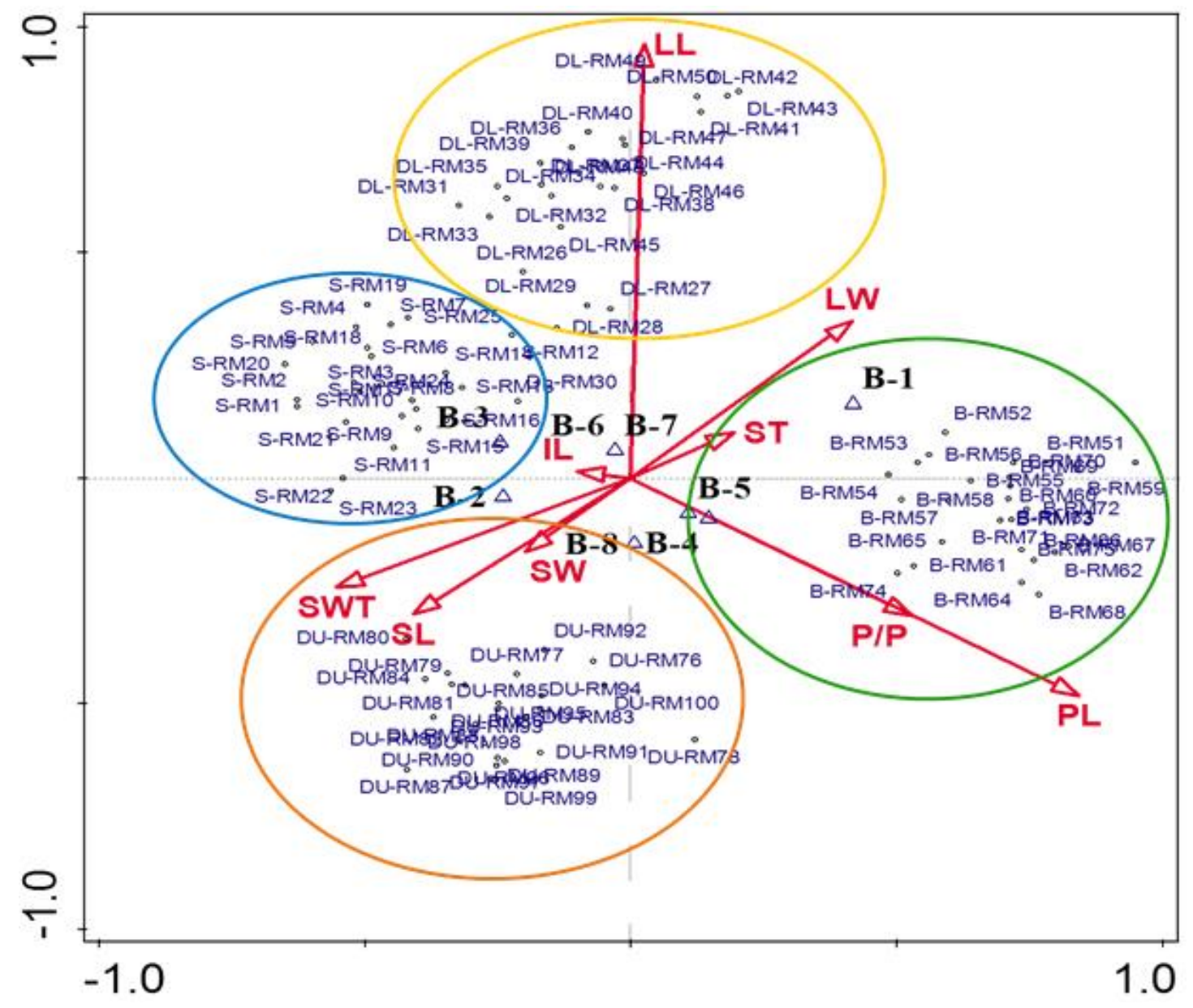

Figure 6. Detrended correspondence analysis (DCA) diagram showing the distribution of $R$. minima genotypes and their association/relatedness based on morphological traits and total seed protein profile

All together, humanity depend on a fraction of the genetic diversity residing in fewer than a dozen of the approximately 300,000 species of angiosperms for $80 \%$ of their caloric intake (McCouch et al., 2013). This is not enough to support our food system in 
the future, and unlike conventional breeding that relies on crossing the best with the best, more predictable breeding outcomes are possible with linkages of genes with specific traits. Wild relatives of crops have tremendous genetic potential that can be released by searching for superior genes. In the past, where the increased crop productivity was based on improved agricultural practices and other changes, future gains will rely on improved genetics (Heslop-Harrison and Schwarzacher, 2012).

\section{Conclusion}

A total of 16 important morphological traits as well as SDS-PAGE of the total seed protein profile were assessed, and the data revealed the existence of ample diversity. Further, cluster analysis based on seed storage protein analyses demonstrated that the 100 genotypes of $R$. minima collected from four districts had close similarities to each other. The SDS-PAGE electrophoresis results also demonstrated that seed protein profiling provides a powerful tool for genotype discrimination based on geographic differences. Furthermore, the results indicate that high variability exists in $R$. minima and that the differences observed among populations were associated with both genetics and geography. Grain legumes are ranked third after cereals and oilseed crops due to their importance for both humans and livestock (Ilyas et al., 2009; Naim-Feil et al., 2017), and therefore, improvements in leguminous crops are of paramount significance. In the future, where adaptation to stresses is likely to address the severity of climate change impacts as well as worldwide food security concerns (Lobell et al., 2008), minor modifications such as changes in sowing dates are helpful to mitigate negative impacts, but long term benefits will be linked to genetic improvements (Heslop-Harrison and Schwarzacher, 2012). Wild crop relatives offer rich sources of genes for resistance to both biotic and abiotic stresses and therefore could improve agriculture (Vavilov, 1940). Nevertheless, $R$. minima, a distant relatives of crop legumes, has so far undergone only limited utilization in foraging as well as for pharmaceutical purposes (Gundidza et al., 2009; Jia et al., 2015), yet it demands attention for the isolation of important phytochemicals and provides an opportunity for widening the genetic base of important legumes.

Acknowledgements. The authors would like to extend their sincere appreciation to the Deanship of Scientific Research at King Saud University for its funding to the Research Group number (RG-1435014).

\section{REFERENCES}

[1] Ali, N. (2012): Molecular markers, cytogenetics and epigenetics to characterize wheatThinopyrum hybrid lines conferring wheat streak mosaic virus resistance. - Doctoral dissertation, University of Leicester, UK.

[2] Ali, N., Heslop-Harrison, J. S., Ahmad, H., Graybosch, R. A., Hein, G. L., Schwarzacher, T. (2016): Introgression of chromosome segments from multiple alien species in wheat breeding lines with wheat streak mosaic virus resistance. - Heredity 117: 114-123.

[3] Azeez, M. A., Morkinyo, J. A. (2004): Electrophoretic characterization of crude leaf protein in Lycopersicum and Trichosanthes cultivars. - African Journal of Biotechnology 3: $585-587$. 
[4] Baudoin, J. P., Marechal, R. (1985): Genetic Diversity in Vigna. - In: Singh, S. R., Rachie, K. O. (eds.) Cowpea Research, Production and Utilization. John Wiley and Sons Ltd, New York, pp. 3-9.

[5] Chen, C., Pan, L., Hu, Y., Hu, Z., Ding, Y. (2006): Analysis of genetic variation of seed proteins in the genus Vigna and among its relatives cultivated in China. - Euphytica 123: 367-378.

[6] Fatokun, C. A., Danesh, D., Young, N. D., Stewart, E. L. (1993): Molecular taxonomic relationships in the genus Vigna based on RFLP analysis. - Theoretical and Applied Genetics 86: 97-104.

[7] Ghafoor, A., Ahmad, Z., Qureshi, A. S., Bashir, M. (2002): Genetic relationship in Vigna mungo (L.) Hepper and Vigna radiata (L.) Wilczek based on morphological traits and SDS- PAGE. - Euphytica 123: 367-378.

[8] Gundidza, M., Gwenu, N., Magwa, M. L., Ramalivhana, N. J., Humphrey, G., Samie, A. (2009): Phytochemical composition and biological activities of $R$. minima. - African Journal of Biotechnology 8: 7221-7229.

[9] Gweru, N., Gundidza, M., Magwa, M. L., Ramalivhana, N. J., Humphrey, G., Samie, A., Mmbengwa, V. (2009): Phytochemical composition and biological activities of essential oil of Rhynchosia minima (L., DC. Fabaceae). - African Journal of Biotechnology 8: 721724.

[10] Hameed, A., Shah, T. M., Atta, B. M., Iqbal, N., Haq, M. A., Ali, H. (2009): Comparative Seed Storage Protein Profiling of Kabuli chickpea genotypes. - Pakistan Journal of Botany 41: 703-710.

[11] Heslop-Harrison, J. P., Schwarzacher, T. (2012): Genetics and Genomics of Crop Domestication. - In: Altman, A., Hasegawa, P. M. (eds.) Plant Biotechnology and Agriculture. Academic Press, Amsterdam, pp. 3-18.

[12] Ilyas, M., Qazi, J., Mansoor, S., Briddon, R. W. (2009): Molecular characterization and infectivity of a Legumovirus (genus Begomovirus: family Geminiviridae) infecting the leguminous weed Rhynchosia minima in Pakistan. - Virus Research 145: 279-284.

[13] Jaaska, V., Jaaska, V. (1990): Isozyme variation in Asian beans. - Botanica Acta 103: 223-322.

[14] Jacobsen, S. E., Sørensen, M., Pedersen, S. M., Weiner, J. (2013): Feeding the world: genetically modified crops versus agricultural biodiversity. - Agronomy and Sustainable Development 33: 651-662.

[15] Jia, X., Zhang, C., Qiu, J., Wang, L., Bao, J., Wang, K., Zhang, Y., Chen, M., Wan, J., Su, H., Han, J. (2015): Purification, structural characterization and anticancer activity of the novel polysaccharides from Rhynchosia minima root. - Carbohyberate Polymer 132: 67-71.

[16] Kaga, A., Tomooka, N., Egawa, Y., Hosaka, K., Kajima, O. (1996): Species relationships in the subgenus Ceratotropis (genus Vigna) as revealed by RAPD analysis. - Euphytica 88: $17-24$.

[17] Laemmli, U. K. (1970): Cleavage of structural proteins during the assembly of the head of bacteriophage T4. - Nature 227: 680-685.

[18] Lepš, J., S`milauer, P. (2003): Multivariate Analysis of Ecological Data Using CANOCO. - Cambridge University Press, New York.

[19] Lioi, L., Sparvoli, F., Bollini, R. (1999): Variation and genomic polymorphism of lectinrelated protein in Lima Bean (Phaseolus lunatus L.) seed. - Genetic Research and Crops Evolution 46: 157-182.

[20] Lobell, D. B., Burke, M. B., Tebaldi, C., Mastrandrea, M. D., Falcon, W. P., Naylor, R. L. (2008): Prioritizing climate change adaptation needs for food security in 2030. Science 319: 607-610.

[21] Lopez, P. L. (2012): Rhynchosia minima. - The IUCN Red List of Threatened Species 2012: e.T19379374A20135353. 
[22] Lu, H., Zhang, J., Liu, K. B., Wu, N., Li, Y., Zhou, K., Ye, M., Zhang, T., Zhang, H., Yang, X., Shen, L. (2009): Earliest domestication of common millet (Panicum miliaceum) in East Asia extended to 10,000 years ago. - Proceedings of the National Academy of Science 106: 7367-7372.

[23] Masood, R., Ali, N., Jamil, M., Bibi, K., Rudd, J. C., Mujeeb-Kazi, A. (2016): Novel genetic diversity of the alien D-Genome synthetic hexaploid wheat $(2 n=6 x=42$, AABBDD) germplasm for various phenology traits. - Pakistan Journal of Botany 48(5): 2017-2024.

[24] McCouch, S., Baute, G. J., Bradeen, J., Bramel, P., Bretting, P. K., Buckler, E., Burke, J. M., Charest, D., Cloutier, S., Cole, G., Dempewolf, H. (2013): Agriculture: feeding the future. - Nature 499: 23-25.

[25] Mirali, N., El-Khouri, S., Rizq, F. (2007): Genetic diversity and relationships in some Vicia species as determined by SDS-PAGE of seed proteins. - Biosystematics Plant 51: 660-666.

[26] Morris, J. B. (2008): Rhynchosia minima (L.) DC. Regeneration, characterization and potential uses for natural products and flavonoids. - Plant Genetic Resources 153: 9-15.

[27] Mujeeb-Kazi, A., Ali, N., Ibrahim, A., Napar, A. A., Jamil, M., Hussain, S., Mahmood, Z., Delgado, R., Rosas, V., Cortes, A., Rajaram, S. (2017): Tissue culture mediated allelic diversification and genomic enrichment of wheat to combat production constraints and address food security. - Plant Tissue Culture and Biotechnology 27: 89-140.

[28] Naim-Feil, E., Toren, M., Aubert, G., Rubinstein, M., Rosen, A., Eshed, R., Sherman, A., Ophir, R., Saranga, Y. and Abbo, S. (2017): Drought response and genetic diversity in Pisum fulvum, a wild relative of domesticated pea. - Crop Science 57(3): 1145-1159.

[29] Nei, M., Li, W. H. (1979): Mathematical model for studying genetic variation in terms of restriction endonucleases. - Proceedings of the National Academy of Sciences 76(10): 5269-5273.

[30] Nisar, M., Ghafoor, A., Khan, M. R., Ahmad, H., Qureshi, A. S., Ali, H. (2007): Genetic diversity and geographic relationship among local and exotic chickpea germplasm. Pakistan Journal of Botany 39: 1575-1581.

[31] Nisar, M., Ghafoor, A., Asmatullah (2009): First proteomic assay of Pakistani Pisum sativum, L. germplasm relation to geographic pattern. - Russian Journal of Genetics 45: 805-810.

[32] Nisar, M., Ghafoor, A., Wadood, S. F., Iqbal, A., Nausheen. (2016): Intra and inter specific profiling of Pakistani Quercus Species growing in hilly areas of District Dir Khyber Pukhtunkhwa. - Pakistan Journal of Botany 48: 263-270.

[33] Patokar, C., Sepsi, A., Schwarzacher, T., Kishii, M., Heslop-Harrison, J. S. (2016): Molecular cytogenetic characterization of novel wheat-Thinopyrum bessarabicum recombinant lines carrying intercalary translocations. - Chromosoma 125: 163-172.

[34] Payne, P. I. (1987): Genetics of wheat storage proteins and the effect of allelic variation on bread-making quality. - Annual Reviews Plant Physiology 38: 141-153.

[35] Rogle, S., Javornik, B., Sinkovic, T., Batic, F. (1996): Characterization of oak (Quercus L.) seed proteins by electrophoresis. - Bioindicator 36: 195-162.

[36] Schwarzacher, T., Ali, N., Chaudhary, H. K., Graybosch, R., Kapalande, H. V., Kinski, E., Heslop-Harrison, J. S. (2011): Fluorescent in situ hybridization as a genetic technology to analyzing chromosomal organization of alien wheat recombinant lines. IAEA-TECDOC-1664: 121-128.

[37] Shaukat, S. S., Burhan, N. (2000): Fecundity, seed characteristics and factors regulating germination of Rhynchosia minima (L.) DC. - Pakistan Journal of Botany 32: 211-226.

[38] Takeda, S., Matsuoka, M. (2008): Genetic approaches to crop improvement: responding to environmental and population changes. - Nature Review Genetics 9: 444.

[39] Tanksley, S. D., McCouch, S. R. (1997): Seed banks and molecular maps: unlocking genetic potential from the wild. - Science 277: 1063-1066. 
[40] Tomooka, N., Maxted, N., Thavarasook, C., Jayasuriya, A. H. M. (2002): Two new species, new species combinations and sectional designations in Vigna subgenus Ceratotropis (Piper) Verdcourt (Leguminosae, Phaseoleae). - Kew Bulletin 57: 613-624.

[41] Vaillancourt, R. E., Weeden, N. F. (1993): Chloroplast DNA phylogeny on old world Vigna (Leguminosae). - Systematic Botany 18: 642-651.

[42] Vavilov, N. I. (1940): The New Systematics of Cultivated Plants. - Huxley, J. (ed.) New Systematics. Clarendon, Oxford, pp. 549-566.

[43] Wadood, S. F., Hassan, N., Khaliq, A., Nausheen, J. T., Ghafoor, A., Khan, M., Nisar, M. (2016): Genetic polymorphism in Lens culinaris collected from Malakand division Khyber Pakhtunkhwa, Pakistan. - Journal of Biology and Environmental Science 8: 5360.

[44] Win, K. T., Zaw, A., New, K. L., Thein, M. S., Yutaka, H. (2011): Diversity of Myanmar cowpea accessions through seed storage polypeptides and its cross compatibility with the subgenus Ceratotropis. - Journal of Plant Breeding and Crop Science 3: 87-95.

[45] Yasui, T., Tateishi, Y., Ohashi, H. (1985): Distribution of low molecular weight carbohydrates in the subgenus Ceratotropis of the genus Vigna (Leguminosae). Botanical Magazine Tokyo 98: 75-82.

[46] Zahoor, M., Nisar, M., Islam, N. U. (2015): Genetic variations of Robinia pseudoacacia plant using SDS-PAGE. - Pakistan Journal of Botany 47: 2335-2338.

\section{APPENDIX}

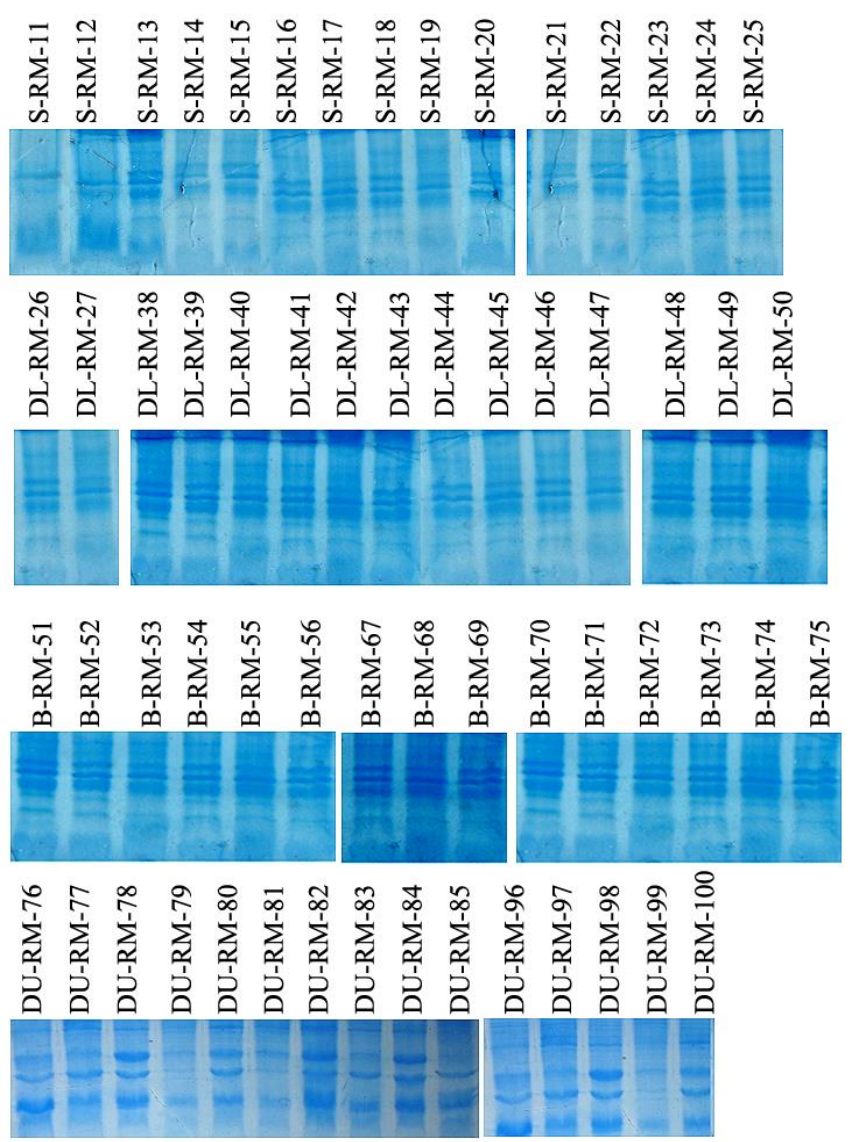

Figure A1. Polyacrylamide gel (12\%) electrophoresis showing diversity in total seed storage protein among different genotypes of $R$. minima collected from four districts of Malakand Division, Pakistan. $S=$ swat, $D L=$ Dir lower, $B=$ buner, $D U=$ Dir upper, $R M=R$. minima 
Table A1. List of R. minima genotypes collected from four districts of Malakand Division, Pakistan

\begin{tabular}{|c|c|c|c|c|c|c|c|c|}
\hline S. No. & Species name & $\begin{array}{l}\text { District of } \\
\text { collection }\end{array}$ & $\begin{array}{c}\text { Specific area of } \\
\text { collection }\end{array}$ & $\begin{array}{c}\text { Accession } \\
\text { No. }\end{array}$ & S. No. & $\begin{array}{l}\begin{array}{l}\text { District of } \\
\text { collection }\end{array} \\
\end{array}$ & \begin{tabular}{|c}
$\begin{array}{c}\text { Specific area of } \\
\text { collection }\end{array}$ \\
\end{tabular} & Accession No. \\
\hline 1. & R. minima & Swat & Ziarat & S-RM1 & 51. & Buner & Karakar & B-RM51 \\
\hline 2. & R. minima & Swat & Swegalai & S-RM2 & 52. & Buner & Jowar & B-RM52 \\
\hline 3. & R. minima & Swat & Dadahara & S-RM3 & 53. & Buner & Toorwarsk & B-RM53 \\
\hline 4. & R. minima & Swat & Kohay & S-RM4 & 54. & Buner & Sawarai & B-RM54 \\
\hline 5. & R. minima & Swat & Gadi & S-RM5 & 55. & Buner & Chamtalai & B-RM55 \\
\hline 6. & R. minima & Swat & Sharif Abad & S-RM6 & 56. & Buner & Matwanai & B-RM56 \\
\hline 7. & R. minima & Swat & Zarakhela & S-RM7 & 57. & Buner & Bara & B-RM57 \\
\hline 8. & R. minima & Swat & Gora Gat & S-RM8 & 58. & Buner & Nawagai & B-RM58 \\
\hline 9. & R. minima & Swat & Chongai & S-RM9 & 59. & Buner & KozaNawagai & B-RM59 \\
\hline 10. & R. minima & Swat & Qabar Shah & S-RM10 & 60. & Buner & Narbatawa & B-RM60 \\
\hline 11. & R. minima & Swat & Landakay & S-RM11 & 61. & Buner & Naway Kalay & B-RM61 \\
\hline 12. & R. minima & Swat & Kota & S-RM12 & 62. & Buner & Anghapur & B-RM62 \\
\hline 13. & R. minima & Swat & Aboha & S-RM13 & 63. & Buner & Derai & B-RM63 \\
\hline 14. & R. minima & Swat & Terang & S-RM14 & 64. & Buner & Amnawar & B-RM64 \\
\hline 15. & R. minima & Swat & Dool & S-RM15 & 65. & Buner & Sangara & B-RM65 \\
\hline 16. & R. minima & Swat & Chargo Tangay & S-RM16 & 66. & Buner & Agarai & B-RM66 \\
\hline 17. & R. minima & Swat & Amlook Garai & S-RM17 & 67. & Buner & Ashezomaira & B-RM67 \\
\hline 18. & R. minima & Swat & Shamra & S-RM18 & 68. & Buner & Bampokha & B-RM68 \\
\hline 19. & R. minima & Swat & Mula Hassan Baba & S-RM19 & 69. & Buner & Balo Khan & B-RM69 \\
\hline 20. & R. minima & Swat & Malak Abad & S-RM20 & 70. & Buner & Bahi Kaly & B-RM70 \\
\hline 21. & R. minima & Swat & Soray & S-RM21 & 71. & Buner & Barjokaney & B-RM71 \\
\hline 22. & R. minima & Swat & Tangai Chena & S-RM22 & 72. & Buner & Bar Kaley & B-RM72 \\
\hline 23. & R. minima & Swat & Qalagay & S-RM23 & 73. & Buner & Beshonai & B-RM73 \\
\hline 24. & R. minima & Swat & Sarkhanai & S-RM24 & 74. & Buner & Bazargey & B-RM74 \\
\hline 25. & R. minima & Swat & Yakhtangay & S-RM25 & 75. & Buner & Mula Banda & B-RM75 \\
\hline 26. & R. minima & Dir lower & Faqir Abad & DL-RM26 & 76. & Dir upper & Batal & DU-RM76 \\
\hline 27. & R. minima & Dir lower & Ramora & DL-RM27 & 77. & Dir upper & Khwage-Oba & DU-RM77 \\
\hline 28. & R. minima & Dir lower & Gul Abad & DL-RM28 & 78. & Dir upper & Bekari & DU-RM78 \\
\hline 29. & R. minima & Dir lower & Shah lam Baba & DL-RM29 & 79. & Dir upper & Patrok & DU-RM79 \\
\hline 30. & R. minima & Dir lower & Ouch & DL-RM30 & 80. & Dir upper & Shoor & DU-RM80 \\
\hline 31. & R. minima & Dir lower & Asbanr & DL-RM31 & 81. & Dir upper & Balkot & DU-RM81 \\
\hline 32. & R. minima & Dir lower & Nawagai & DL-RM32 & 82. & Dir upper & Jandrai & DU-RM82 \\
\hline 33. & R. minima & Dir lower & Khwas & DL-RM33 & 83. & Dir upper & Islam-Gat & DU-RM83 \\
\hline 34. & R. minima & Dir lower & Totano Bandai & DL-RM34 & 84. & Dir upper & Jelar & DU-RM84 \\
\hline 35. & R. minima & Dir lower & Bambolai & DL-RM35 & 85. & Dir upper & Kakad & DU-RM85 \\
\hline 36. & R. minima & Dir lower & Kityari & DL-RM36 & 86. & Dir upper & Haji Shai & \begin{tabular}{|l|} 
DU-RM86 \\
\end{tabular} \\
\hline 37. & R. minima & Dir lower & Shwa & DL-RM37 & 87. & Dir upper & Kharkani & DU-RM87 \\
\hline 38. & R. minima & Dir lower & Badwan & DL-RM38 & 88. & Dir upper & Thal & DU-RM88 \\
\hline 39. & R. minima & Dir lower & Dalbar & DL-RM39 & 89. & Dir upper & Kalkot & DU-RM89 \\
\hline 40. & R. minima & Dir lower & Laaram & DL-RM40 & 90. & Dir upper & Lamotai & DU-RM90 \\
\hline 41. & R. minima & Dir lower & Sarkhanai & DL-RM41 & 91. & Dir upper & Jagram & DU-RM91 \\
\hline 42. & R. minima & Dir lower & Jawaro & DL-RM42 & 92. & Dir upper & Bandagai & DU-RM92 \\
\hline 43. & R. minima & Dir lower & Babar Ghakhey & DL-RM43 & 93. & Dir upper & Karodara & DU-RM93 \\
\hline 44. & R. minima & Dir lower & Medan & DL-RM44 & 94. & Dir upper & Warai & DU-RM94 \\
\hline 45. & R. minima & Dir lower & \begin{tabular}{|l|} 
Talash \\
\end{tabular} & DL-RM45 & 95. & Dir upper & Laspoor & \begin{tabular}{|l|} 
DU-RM95 \\
\end{tabular} \\
\hline 46. & R. minima & Dir lower & Fingal & DL-RM46 & 96. & Dir upper & Mastooj & DU-RM96 \\
\hline 47. & R. minima & Dir lower & Bagh & DL-RM47 & 97. & Dir upper & Drosh & DU-RM97 \\
\hline 48. & R. minima & Dir lower & Khaal & DL-RM48 & 98. & Dir upper & Ashreet & \begin{tabular}{|l|} 
DU-RM98 \\
\end{tabular} \\
\hline 49. & R. minima & Dir lower & Rabaat & DL-RM49 & 99. & Dir upper & Domail & DU-RM99 \\
\hline 50. & R. minima & Dir lower & Kotigram & DL-RM50 & 100. & Dir upper & Qashqar & DU-RM100 \\
\hline
\end{tabular}

